\title{
Main street plot scale in urban design for inclusive economies: Stockholm case studies
}

\author{
Rosa Danenberg ${ }^{a} \quad$ Michael Mehaffy ${ }^{a}$ \\ Sergio Porta ${ }^{b}$ \\ Peter Elmlund ${ }^{c}$ \\ ${ }^{a} \mathrm{KTH}$ - Royal Institute of Technology \\ bUniversity of Strathclyde \\ ${ }^{\mathrm{c}}$ Axel and Margaret Axson Johnson Foundation
}




\section{Abstract}

This paper explores evidence that entrepreneurial opportunities for migrants and other lower income populations can be expanded in part through increasing the presence of fine grained scales of plots and plates along main streets, as part of a systematic urban design strategy. It describes that systematic strategy herein. The paper encompasses the study of three main streets with varying plot sizes in the inner city of Stockholm, Sweden, and examines the outcomes for different types and scales of businesses. After presenting the findings, analysis and conclusions, larger questions of urban design for more inclusive economies are discussed.

\section{Keywords}

Buildings, structures \& design, Social impact, Town \& city planning 


\section{Introduction}

2 Recent years have seen a surge of research and policy interest in so-called "main streets" or

3 "high streets" -- that is, streets with a broad range of retail and non-retail activities, often with a

Simultaneously, in many European cities, a contrary trend marks the increase of ethnic entrepreneurs on main streets (Carmona et al., 2015, p.7; Hall, 2011, Zukin et al., 2016). A number of researchers have noted the importance of this trend in providing economic opportunities by migrant communities seeking employment and/or entrepreneurial activities (Favell and Hansen, 2002; Hall, 2015; Zukin et al., 2016). What is at stake, they note, is not only the benefits to migrants from participation in the local economic and cultural life of the city, but the economic productivity of the city itself, given the positive contribution of migrants to local economies, the "local multiplier effect" of local entrepreneurial activity and employment, and the upward mobility offered by what the journalist Doug Saunders has termed 'Arrival Cities' 
However, research on ethnic entrepreneurship has often neglected the spatial dimension, thereby neglecting the fact that location matters (Rekers \& Van Kempen, 2000; Lo \& Teixeira, 2015). The value of small, local, independent businesses proves to be strongly linked to spatial dimensions. In fact, according to Rekers and Van Kempen,

"...the spatial structure of the city is important with respect to business premises. In many Western European countries an enormous difference exists between prewar and postwar neighbourhoods. In older neighbourhoods, shops and other enterprises grew up more or less spontaneously around daily markets and in several streets throughout the area. These premises are now being occupied by new users, including ethnic entrepreneurs." (Rekers \& Van Kempen, 2000, pp.65-66).

Ethnic entrepreneurs (including immigrants) are typically engaged and embedded in the community, resulting in place management partnerships, community participation, and selforganization (Parker et al., 2014). Within the local community, relatives, acquaintances and/or employees from similar backgrounds tend to be employed in the migrant businesses and use the opportunity to learn entrepreneurial skills (Khosravi, 1999). Ethnic vertical integration also reduces transaction costs (Raijman \& Tienda, 2003).

Against this backdrop, the "alterations in scale" of urban morphology, as a "signature" of postWWII urbanism (Porta et al., 2014), and especially the morphological structure of main streets for diversity of ground floor spaces to provide diversity of ethnic businesses (Vaughan et al, 2017), emerges as a key question. Specifically, one may ask, are there attributes of urban morphology and scale that improve, or conversely degrade, entrepreneurial opportunities for migrants? What businesses tend to be owned by migrants, in what kind of premises, and how have they changed in the past ten years?

In this research, it is therefore asked, is there a correlation between the scale of plots and/or the plates on main streets, and the evidence of entrepreneurial opportunity and economic productivity by migrant populations? If there is a correlation, can causation be inferred? This 

and draws conclusions and discusses topics for further research.

63

\section{Plot-Based Urbanism as a conceptual framework} expressions of design creation (Romice et al., 2017b; Dibble et al., 2017).

paper examines the specific case studies of three inner city main streets in Stockholm, Sweden,

This research builds on the contributions of "Plot-Based Urbanism" (PBU), a conceptual and methodological framework for contemporary urban design and masterplanning. Broadly speaking, Plot-Based Urbanism focuses on the scale of the plot, the plot's relationship with street types and land uses in time, and its critical impact on urban processes including economic, to inform masterplanning practice. An articulation of the place-making approach to urban design (Porta and Romice, 2014), PBU stresses the importance of establishing in places the appropriate spatial conditions for the self-organization of non-spatial dynamics, such as commercial, cultural and social. Self-organization is therefore intended to be complementary, rather than alternative, to spatial planning, as long as the latter is made "time-conscious" (Thwaites et al., 2007). The latest developments of the PBU approach more clearly recognise the evolutionary nature of urban form and, along this line, the primary importance of people's "informal participation" in fuelling the trajectory of change of places (Romice et al., 2017a): by doing so, PBU reconnects past forms of masterplanning that have generated adaptive and continuously successful places over time (Barbour et al., 2016), to the desirable goal of resilient and democratic future cities in the urbanization age (Porta et al., 2018). PBU informs a radical "rethinking the masterplanning practice", in search of a way to design places that understands and embraces continuous evolutionary change rather than conceiving them as untouchable

In a PBU perspective, a correct understanding of main streets can make a whole difference in the way future cities are shaped. Evidence has been raised many times in support of the idea that main streets are the backbones of our best urban communities (Porta et al., 2012), and tend to be stable in time (Strano et al., 2012; Strano et al., 2013). Properly structured, fine grained main streets are in fact fundamentally important to the shaping of resilient urban communities (Mehaffy et al., 2010): independently controlled plots of appropriate sizes on main streets can meaningfully expand entrepreneurial opportunities and non spatial patterns that are 
91 highly responsive to changing conditions in time. In a parallel relationship to other complex adaptive systems (Holling and Goldberg, 1971), adaptive and resilient places are characterised by five main properties, or "resilience proxies" — namely diversity, connectivity, redundancy, modularity and efficiency-which operate at scale, for example at the plot scale (Feliciotti et al., 2016; Feliciotti et al., 2017). Moreover, "good" places are made of urban elements that are strictly interconnected across scales, in order to allow "panarchic" change enlivening their evolution, in the same way it does to all complex-adaptive systems in nature, culture and the society (Gunderson and Holling, 2002; Holling, 2004). In this sense, resilience thinking reveals to us the crucial importance of the dynamics of change that is investigated in this research, which typically involve different systems (urban form and retail commerce) that are interconnected in space at different scales (plot, street edge, street network). Similar crossscalar patterns have been at the centre of Jane Jacobs' notion of aged buildings as important features of successful streets that provide different levels of access to a broader spectrum of business types (Sardari Sayyar \& Marcus, 2013). More plots, in this sense, are more likely to contribute to more diversity of economic activity. As famously noticed in Stockholm by Hall (2009, p.78):

"Investments by private individuals, as we have seen, were necessary if houses were to be built on plots, and 'plot-jobbing' was not regarded as dubious; it was the only option for people with small means, for example, craftsmen and lower white-collar workers, to rise quickly to a higher social and economic level" (Hall, 2009, p.78).

\section{"Plots" and "plates"}

This study also extends the inquiry beyond plots - that is, legal property lines and/or units of uninterrupted accessibility - and into the plate spaces of buildings, occupied by a variety of individual tenants. For convenience, these spaces are referred to as "plates" (short for floorplates). While there are differences in ownership status between "plots" and "plates", and it is easier to change the boundaries of plates over shorter periods of time, these are differences of degree. It is therefore important to assess the opportunities for migrants as they relate to the scale of both plots and plates. 
In both cases it can be asked what relation the size of these structures has to migrant opportunities in Stockholm. It is hypothesized that a more flexible, more adaptive built environment is expected to offer better spatial conditions for accommodating the needs and values of new users, especially startup businesses. This paper focuses on the plot and plate size and ethnic entrepreneurship in particular as proxies of the capacity of space to welcome change by constant adaptation and informal participation.

The research questions, then, are: can a correlation be observed between the scale of plots and plates, and the indicators of migrant economic and social opportunities? Can any reliable evidence be identified that the scale of these structures plays a role? Do new research questions emerge meriting further research?

\section{Case study background}

\subsection{Background to urban development in Stockholm}

Urbanisation occurred in Stockholm at a relatively late stage in the XIXth century (Nyström \& Lundström, 2006; Hall, 2009). In anticipation to industrialization and population growth, and inspired by European counterparts such as Haussmann's vision for Paris, the 1866 Lindhagen plan laid out a masterplan including a grandiose street network resulting in the implementation of a rigid street grid, broad thoroughfares and integrated green spaces (Hall, 2009). A national building statute issued in 1874 established that "[s]treets were to be at least 18 metres wide and buildings a maximum of 19.5 meters or five storeys high, but no higher than the width of the street, and [...] that at least one-third of each plot should be left unbuilt as courtyard" (p.78). These codes informed the straightening and widening of the three streets selected for this study: Odengatan, Hantverkargatan, and Hornsgatan. The next large city expansion occurred under the rules of Modern neighbourhood planning in the 1940s (Nyström \& Lundström, 2006). Suburban developments were purposefully designed to avoid fine-grained retail commerce, to be replaced by cultural and institutional facilities that were meant to express democratic values and attract social interaction. Thus, the historical inner city, with its street network and retail functions at the ground floor, still remains today the central magnet of consumption and leisure 
151 in Stockholm. Since the 1960s, the focus has shifted from expanding strategies to infill

152 development and consequently densification of developed land (Hall, 2009). Arguably,

153 Stockholm is currently in the midst of the next large city expansion by densification strategies

154 wherein the quality of public space, diversity of people and district identities, and citizen

155 participation are promoted (Stockholms Stad, 2018).

156

\subsection{Entrepreneurship in Stockholm and Sweden}

158 Stockholm is a growing city with $17 \%$ increase between 2008 and 2017 reaching almost a

159 million inhabitants in the metropolitan area, $24 \%$ of which have a foreign background (Statistics

160 Stockholm, 2017). Similarly, Sweden has never seen such a large population, not the least due to influx of immigrants; in 2017, citizens with a foreign background increased with $14 \%$ compared to 2016 and its total population increased with $1.2 \%$ reaching more than ten million inhabitants (Statistics Sweden, 2018). Observing the past ten years, Sweden has seen a 40\% increase in newly registered companies and Stockholm even a 51\% increase (Bolagsverket, na). However, looking at small firms, the number of new sole traders as well as totally registered sole traders in Sweden has decreased with $40 \%$ which is about the same in Stockholm. Nevertheless, according to the Swedish Agency of Economic and Regional Growth, particularly migrant entrepreneurs have increasingly started businesses, accounting for $13 \%$ in 2012 and $15 \%$ in 2014 of the total number of businesses, with a higher share in small businesses (accounting up to 9 employees) (Tillväxtverket, 2013; 2015). Thus, while native sole traders have decreased, migrant sole traders have increased, denouncing that

"the self-employment sector has thus become a source of employment that plays an important role in the assimilation of immigrants" (Hammarstedt, 2004, p.115).

176 For immigrants in Sweden, it appears harder to find employment on the job market, which

177 makes entrepreneurship often a forced choice. Obstacles such as bureaucracy, access to 178 capital and language and/or cultural barriers are more prevalent among job-seekers with a 179 foreign background (Khosravi, 1999; Tillväxtverket, 2013; 2015). Nonetheless, migrant 
180

entrepreneurs in Sweden tend to have higher ambitions and expectations for the company to grow, specifically in number of employees (Tillväxtverket, 2015).

\subsection{The case studies}

This study selected streets in three inner city areas of Stockholm, Sweden: Odengatan (Norrmalm), Hantverkargatan (Kungsholmen), and Hornsgatan (Södermalm). See Figure 1. The criteria that led to the identification of the aforementioned three streets for this research are many. Firstly, their strategic location in the inner city of Stockholm, as each street is located in the centre of an area connecting east-west linkages close to well-connected major transportation hubs, and has subways and local and city busses running through. Secondly, the inner city is significantly different from the suburban outer city. Stockholm metropolitan area, as many other European cities, is challenged with unequal living conditions, social and ethnic segregation and unequal availability to services and labour market (Legeby, 2009). In contrast to outer city suburbs, the inner city attributes higher retail diversity in terms of intensity, better internal accessibility as well as to other economic activities; has a self-organizing (market) driven retail system as opposed to the suburban planned (publicly or privately) retail system; a larger size of local market for retail activities; and a higher number of plots (Sardari Sayyar \& Marcus, 2013). This arguably creates a reasonable market for retail in the inner city. The perception that ethnic entrepreneurship is restricted to migrant-dense neighbourhoods is not always true, especially not when the targeted clientele is located in the inner city (Lidola, 2014). Furthermore, for the selection of the three streets, the island-structure of the inner city of Stockholm naturally allows for clearly defined areas with distinct identities. Norrmalm (Odengatan) and Kungsholmen (Hantverkargatan) have around 70.000 inhabitants while Södermalm (Hornsgatan) houses around 125.000. In addition, the working population represents respectively $15.000,22.000$, and 12.000 work places. Administratively, the areas are divided into smaller districts, configuring the main streets neighbourhoods that have respectively $30.000,20.000$, and 15.000 inhabitants. Albeit the distinct identities, the area and population characteristics among the streets are rather similar: mainly higher educated and middle to upper class of which around 15\% are foreign born (Statistik Stockholm, 2017). Therefore, studying the three streets in a comparative manner may be in interesting for finding similarities or differences 
210 between the areas. Thirdly, the change of the inner city ground floor in relation to the building

211 ownership is interesting since between 1990 and 2014 around half of the rentals apartments

212 have been transformed into condominiums (Statistics Stockholm, 2017). The residents lease

213 apartments with the right of tenant ownership. The tenant-owner's association owns and

214 manages the building through a governing board that decides on the finances and property

215 management.

[Figure 1]

217

\section{Data from cases}

219 The three inner city main streets present remarkable similarities regarding spatial structures as well as changes in type of business and type of entrepreneurship between 2009 and 2018 that allow for generalizations among the streets. This study examined both "plots" (legal property lines) and "plates" (floorplates within buildings that are demised for leasing). The plots are often measured as not smaller than $200 \mathrm{~m}^{2}$ while the plates are sometimes as small as $40 \mathrm{~m}^{2}$, which is a size typical of a small business. Data of the three streets are combined and processed with a statistical tool to produce the following findings. All data presented in this paper have been checked for correlation and have passed the significance test.

Table 2 presents the size and scale of the plates. The method used to measure the plate is based on an approximation combining a map measure tool and personal observation.

235 Furthermore, the plates have been categorized by size: small, medium, large and extra large plates based on the author's judgement. The larger non-commercial institutions have been detected as outliers and have been removed (Missing values: Odengatan 14; Hantverkargatan 15; Hornsgatan 15). 


\subsection{Changes in type of business}

242 Table 3 shows the changes between what business was there in 2009 and in 2018. The open

243 source tool Google Street View has been utilized for observations in 2009 (and if not available

244 then used 2011) complemented with personal observations. Comparing 2009 and 2018, the

245 findings show that almost half of the plates have changed in the past ten years. Also, a few

246 plates have been split and merged, ultimately resulting in slightly lower number and thus larger 247 plates in 2018.

[Table 3]

249 For the categorization of the type of businesses, see table 4.

250

[Table 4]

251 For the changes of the type of business see table 5.

252

[Table 5]

253 This study takes an interest in where these changes take place and whether the morphological

254 setting can offer an explanation. At street level, the findings tell us that the changes are

255 randomly spread over the street, but that the change is related to plate size: businesses located

256 in small and medium plates have changed more than in large and extra large plates

$257(\chi 2(1, \mathrm{~N}=686)=8.7, \mathrm{p}<, 003)$. More specifically, the small plates change more radically

258 (i.e. from category 'Retail Product Stores' to 'Personal Beauty Services' as opposed to a change within same category) $(\chi 2(1, \mathrm{~N}=686)=3.9, \mathrm{p}<, 046)$. 'Personal beauty services' are to

260 larger extent situated in small plates $(\chi 2(1, \mathrm{~N}=686)=31.0, \mathrm{p}<, 000)$ while 'Food and Drink services' are to larger extent situated in medium plates $(\chi 2(1, \mathrm{~N}=686)=6.2, \mathrm{p}<, 013)$.

262 'Retail product stores' show no relation to a specific size of plate.

263

\section{$264 \quad 4.2$ Changes in entrepreneurship}

265 Through a mix of methods used to triangulate the type of entrepreneurship (Internet searches,

266 personal observations, informal interviews, and online data registers), it has been possible to

267 draw categories. Sole traders, family and local businesses are firms where either the shop

268 owner works in the shop or is personally involved in the daily management. Local companies have been recognized by more than three employees and where the business owner is not 
always present in the shop. International and national chains are formulas that are run as branches with recognizable products, branding and marketing. Regional chains are stores with the same brand located in Stockholm county.

All the streets demonstrate a decrease of sole traders, family businesses, and local companies and an increase in chains, particularly regional city chains. Migrants tend to be mostly sole traders, followed by local companies and regional chains owners. See table 6 .

[Table 6]

The findings show that sole traders, family and local companies are more situated in small and medium plates than in large and extra large plates $(\chi 2(1, \mathrm{~N}=686)=57.8, \mathrm{p}<, 000)$. Also, sole traders are mostly situated in small plates $(\chi 2(1, \mathrm{~N}=686)=104.6, \mathrm{p}<, 000)$. Relating the type of business to the type of entrepreneurship, it can be observed that 'Food and Drink services' are mostly run by local companies $(\chi 2(1, \mathrm{~N}=686)=66.6, \mathrm{p}<, 000)$ and regional chains $(\chi 2(1, \mathrm{~N}=686)=33.7, \mathrm{p}<, 000)$. 'Personal beauty services' are mostly run by sole traders $(\chi 2(1, \mathrm{~N}=686)=44.3, \mathrm{p}<, 000)$

\subsection{Radical change in plate size as entrepreneurial opportunities for migrants}

To test for how the variables of plate size, type of business and type of entrepreneurship could potentially generate entrepreneurial opportunities for migrants and lower-income populations, each of the business is coded in a range of migrant businesses. Migrant businesses have been identified as an ethnic-themed company run by migrant (e.g. Indian restaurant run by Indian migrant) and neutral company run by migrant (e.g. nail salon run by Vietnamese couple). Online databases featuring company registration information, homepages, as well as personal observations has led to the categorization of migrant businesses.

The data shows that migrant businesses have increased as more businesses from 2009 that changed have become migrant-driven businesses. Migrant businesses are more situated in small plates $(\chi 2(1, \mathrm{~N}=686)=17.1, \mathrm{p}<, 000)$. Migrants drive mostly 'Food and Drink services' services' $(\chi 2(1, \mathrm{~N}=686)=54.5, \mathrm{p}<, 000)$ and 'Personal beauty services' 
$299(\chi 2(1, \mathrm{~N}=686)=16.6, \mathrm{p}<, 000)$. And they are more run by sole traders or family business

300 followed by local companies $(\chi 2(1, \mathrm{~N}=686)=62.4, \mathrm{p}<, 000)$.

301

302

303

304

305

306

307

308

309

310

311

312

313

314

315

316

317

318

319

320

321 322

323

What can be observed from the findings is that there are significant relationships between the variables: plate size, type of business, type of entrepreneurship and whether the business is run by a migrant entrepreneur through measuring the change in time. Since the small plates change often and change most radically, it appears that such spaces are more flexible with regard to any kind of plate activity. This creates entrepreneurial opportunities both for migrants and for lower-income populations seeking to start a small business requiring lower startup capital, which is typical for personal beauty services as well as food and drink services. However, those types of business categories show different tendencies and characteristics while both show similar significant correlations to migrant entrepreneurship. The variance indicates that 'Personal beauty services' are more often sole traders and situated in small plates, while 'food and drink services' are more often regional chains or local companies and situated in medium-size plates. This finding however does not necessarily point toward a standard retail model, but indicates only that the variables are significantly correlated in the case study areas.

\section{Discussion}

Each individual street as a micro-space has its own particular dynamics within its context.

However, intriguingly, this study shows the parallels between all three streets in terms of change of retail and entrepreneurship in relation to morphology. Based on the similarity of the built form of every street, the results could imply that the morphological structures of a street as well as the degree of inner city centrality are determiners for the kind of change happening on a street.

The fact that around one out of two businesses changed in the past ten years could be an alarming signal for businesses that fail. However, a more holistic interpretation suggests that there is probably a combination of processes at stake. For instance, businesses may simply move to other streets, the owner may retire, a well-running business is bought up and renamed, and so forth. Griffiths (2014) emphasizes the natural evolution of main streets, providing space for negotiating social change as a 'dynamic agent of continuity' (2014, p.39). In fact, 
many chains started on main streets before relocating to larger shopping streets (Sangani \& Stephans, 2011). Moreover, our findings support the creative and innovative nature of main streets for startups. Historic changes on main streets also took place some twenty years ago, including alterations in physical form, use, economic value and social significance (Dawson, 1988).

Interestingly, the results of this research go hand in hand with national economic development trends, showing decreasing numbers of sole traders and increasing companies and migrant businesses (Tillväxtverket, 2015). It can be observed, then, that main streets are a symbolic and representative urban element that reflects wider social and economic trends.

The results of this study demonstrate the stability of the large and extra-large plates while the small and medium plate sizes generate more dynamism and change that allow for opportunity. At the same time, it is probably not feasible (or even desirable) to have only small and medium plates with small-scale local companies. Rather, a mix of sizes allows for healthy adaptability and vitality of the entire street. Since the size of the plate is a determinant factor for a chain or local company, with a mix of scales it is easier to ensure a right balance between chains and local companies (see Litvin \& Rosene, 2017; Litvin \& DiForio, 2014).

The presence of small and medium plates has in the past been associated with the presence of sole traders, local firms and family businesses. In contrast, what can be seen now, and not only in Stockholm but also e.g. in London (see Hall, 2011), is the increase of small scale retail chains oriented towards food and drink services, a trend that is parallel to the increase of small, local and independent migrant businesses. The latter are oriented towards not only food and drink services but also personal beauty services, which are both increasingly run by migrants on main streets. Food and drink services target mostly the medium size plates whereas the personal beauty services target the small size plates. The result that can be foreseen is that small, local and independent businesses currently situated in small and medium plates in main streets experience competition from highly adaptable chains that have longer opening hours and subsequently higher turnover, facing the risk that rents will be adjusted to those. Without 
effective policies and planning regulations to protect the value of small entrepreneurship on main streets, the city misses the potential for generating entrepreneurial opportunities for migrant and lower-income populations.

362

363

The increase of regional chains triggers conflicting values: on the one hand, with the influx of retail chains, all streets are going to look the same, which, according to surveys, is a negative factor for many residents. Distinct character and identity difference between the areas in Stockholm are likely to be erased as these areas are homogenized, in part because of the disappearance of small, local and independent businesses.

On the other hand, the rise of chains might in fact generate opportunities for migrants and lower income populations. The regional chain owners might also be locally-based entrepreneurs who started with one business and managed to expand their small-scale business in another street in the city. Without much effort, since the formula can be exactly the same, these migrantoperated businesses can be meaningfully expanded as local chains. This might be an attractive model in particular for migrant entrepreneurs that are known to want to expand (Tillväxtverket, 2015). Indeed this could be a successful entrepreneurial strategy, as Khosravi (1999) concluded that two businesses can lower the risk of running a single business. In fact, the expansion of an independent migrant business to a city chain may create multiplier effects for workplaces shaped for co-ethnic employees or forms of ethnic vertical integration.

However, the limitations of self-employment for migrants as a way of improving standards of living and reducing social exclusion must also recognized. Migrants engaged in selfemployment tend to have lower incomes compared to self-employed indigenous Swedes (Slavnic, 2013).

\section{Conclusion}

This research has found a correlation between the scale of plates of ground floor spaces on main streets and the evidence of entrepreneurial opportunity and economic productivity by migrant populations. The results indicate a correlation between small and medium size plates 
and certain types of businesses (especially food and drink services and personal beauty

417 Finally, this paper concludes that the use of fine-grained and varied plot and plate scales must 418 service) with a correlation between larger sizes and lower levels of entrepreneurship by sole traders, family businesses and local companies often driven by migrants.

At the same time, regional chains are targeting the same plate sizes and types of businesses, sometimes displacing migrant entrepreneurs, but also sometimes providing opportunities for migrants to start their own chains. In this sense, the picture for migrant opportunities in relation to pressure from chain businesses is somewhat mixed. There is certainly a potential impact from chains (both local and otherwise) on the character and neighbourhood identities of the city, which also needs to be assessed.

Generally, older masterplanning and building planning that provided smaller plots and plates also created ample opportunities for migrants. Part of the opportunity undoubtedly comes from the age of the buildings, translating into more affordable space - a point made famously by Jane Jacobs (1961). But as this study shows, varied plot and plate scale is one of the effective policies and planning regulations needed to guide the adaptability of main streets, and to provide continued opportunities for ethnic entrepreneurs to situate themselves on main streets.

This research has highlighted a number of areas that warrant further research. As noted above, there is a question whether the introduction of chain retailing is a net reduction or net expansion of opportunities for migrants. In addition, there is a question of the different effects of plots (legal property boundaries) and the other spaces that are termed "plates" (leased areas within larger buildings and plots). Since plates can be more easily modified over time, it would be instructive to see if there is a difference in the rates in which smaller scale spaces are maintained. Lastly, and perhaps most important, it would be helpful to compare other kinds of streets, particularly streets with greater variations in age and morphology, to either verify or contradict the initial findings here of a correlation between migrant opportunity and smalls plot and plate sizes. be part of a wider set of tools and approaches to design places that embrace continuous 
419 evolutionary, change, rather than conceiving of places as untouchable expressions of design 420 creation. To take the latter approach is to fail to recognize the need for all citizens, including 421 low-income and migrant populations, to take their place within the life of the city.

422

423

424 425 435

\section{Acknowledgements}

The authors would like to acknowledge the Ax:son Johnson Foundation for its financial support of the research project "Migrant Economy in Main Streets" at KTH Royal Institute of Technology, Stockholm, Sweden and as well as the research conducted within the Urban Design Studies Unit at University of Strathclyde, Glasgow, UK.

\section{References}

Barbour G, Romice O, and Porta S (2016) Sustainable Plot-Based Urban Regeneration and Traditional Masterplanning Practice in Glasgow. Open House International 41(4): 15-22.

Bolagsverket (na) Statistik om företag och föreningar. See http://bolagsverket.se/be/sok/etjanster/statistik/statistik-1.3538 (accessed 29/05/2018).

Carmona M, David M, Scott F, et al. (2015) London's local high streets: The problems, potential and complexities of mixed street corridors. Progress in Planning 100: 1-84.

Dawson JA (1988). Futures for the high street. The Geographical Journal 154(1): 1-22.

Dibble J, Prelorendjos A, and Romice O, et al. (2017) On the origin of spaces: Morphometric foundations of urban form evolution. Environment and Planning B: Urban Analytics and City Science: 1-24.

Favell A and Hansen R (2002) Markets against politics: migration, EU enlargement and the idea of Europe. Journal of Ethnic and Migration Studies 28(4): 581-601. 
448 Feliciotti A, Romice O and Porta S (2016) Design for Change: Five Proxies for Resilience in the 449 Urban Form. Open House International 41(4): 23-30.

450

451 Feliciotti A, Romice O and Porta S (2017) Urban regeneration, masterplans and resilience: the 452 case of the Gorbals in Glasgow. Urban Morphology 21(1): 61-79.

453

454

Hall T (2009) Metropolitan Stockholm. Routledge, New York. NY, USA

455

456

Hall SM (2011) High street adaptations: ethnicity, independent retail practices, and Localism in 457 London's urban margins. Environment and Planning A 43(11): 2571-2588.

458

459

Hall SM (2015) Migrant urbanisms: Ordinary cities and everyday resistance. Sociology 49(5):

460 853-869.

461

Hammarstedt M (2004) Self-employment among immigrants in Sweden-an analysis of 463 intragroup differences. Small Business Economics 23(2): 115-126.

464

465

Griffiths S (2015) The High Street as a Morphological Event. In The Suburban Urbanities 466 (Vaughan L (ed)). UCL Press, London, UK, pp. 32-50.

467 468

Hillier B (1996) Cities as movement economies. Urban Design International 1(1): 41-60. 469

Holling CS and Goldberg MA (1971) Ecology and planning. Journal of the american Institute of Planners 37(4): 221-230.

472

473 Jacobs J (1961) The Death and Life of Great American Cities. New York: Vintage Books 474

475 Khosravi S (1999) Displacement and entrepreneurship: Iranian small businesses in Stockholm. Journal of Ethnic and Migration Studies 25(3): 493-508. 
478 Nyström L and Lundström MJ (2006) Sweden: The Life and Death and Life of Great

$479 \quad$ Neighbourhood Centres, Built Environment 32(1): 32-52.

480

481 Legeby A (2009) Accessibility and Urban Life: Aspects on Social Segregation. In Proceedings of 482 the 7th International Space Syntax Symposium (D Koch, L Marcus, J Steen (eds)). KTH, $483 \quad$ Stockholm, Sweden, ref. 064: 1-11.

484

485 Lidola M (2014) Negotiating integration in Berlin's Waxing Studios: Brazilian migrants' gendered 486 appropriation of urban consumer spaces and 'ethnic' entrepreneurship. Journal of 488

Litvin SW and Rosene JT (2017) Revisiting Main Street: Balancing Chain and Local Retail in a 490 Historic City's Downtown. Journal of Travel Research 56(6): 821-831.

491

Litvin SW and DiForio J (2014) The "malling" of Main Street: The threat of chain stores to the 493 character of a historic city's downtown. Journal of Travel Research 53(4): 488-499. 494

495 Lo L and Teixeira C (2015) Sustaining Immigrant Entrepreneurship in Small-and Medium-sized 496 Cities. Journal of Entrepreneurship and Innovation in Emerging Economies 1(2):146-162. 497

498 Mehaffy MW, Porta S, Rofè Y, et al. (2010) Urban nuclei and the geometry of streets: The 499 ‘emergent neighborhoods' model. Urban Design International 15(1): 22-46.

500

501 Moretti E (2010) Local Multipliers. American Economic Review: Papers and Proceedings. 100: 502 $1-7$.

503

504 Moretti E and Thulin P (2013) Local multipliers and human capital in the United States and $505 \quad$ Sweden. Industrial and Corporate Change 22(1): 339-362.

506 
507 Parker C, Ntounis N, Quin S, et al. (2014) High Street research agenda: identifying High Street

508 research priorities. Journal of Place Management and Development 7(2): 176-184.

509

510 Porta S, Latora V, Wang F, et al. (2012) Street Centrality and the Location of Economic

$511 \quad$ Activities in Barcelona. Urban Studies 49(7): 1471-1488.

512

513 Porta S and Romice O (2014) Plot-Based Urbanism Towards Time Consciousness in Place

514 Making. In: Mäckler CS, Wolfgang (ed) New Civic Art. Sulgen, CH: Verlag Niggli, 82-111.

515

516 Porta S, Romice O, Feliciotti A, et al. (2018) Big box, short life: little box, long life: the democracy of resilience: plot-based urbanism, evolution and informal participation. Create Streets. London, UK. See http://dev.createstreets.com/wp-content/uploads/2018/01/Big-Box-

520

521

Porta S, Romice O, Maxwell JA, et al. (2014) Alterations in scale: Patterns of change in main 522 street networks across time and space. Urban Studies 51(16): 3383-3400.

523

524

525

Raijman R and Tienda M (2003) Ethnic foundations of economic transactions: Mexican and Korean immigrant entrepreneurs in Chicago. Ethnic \& Racial Studies 26(5): 783-801.

526

527

Rekers A and Van Kempen R (2000) Location matters: ethnic entrepreneurs and the spatial 529

530 Romice O, Feliciotti A and Porta S (2017a) The Road to Masterplanning for Change and the Design of Resilient Places. Architectural Research in Finland 1(1): 11-26.

532

533

Romice O, Porta S, Feliciotti A, et al. (2017b) Masterplanning for Change: Design as a Way to Create the Conditions for Time-Sensitive Place-making In: AlWaer H and Illsely B (eds) Placemaking: Rethinking the Masterplanning Process. ICE Publisher, London, UK: pp.195207. 
Sangani J and Stephans S (2011) The Economic Value of Main Streets: an Assessment of the Economic Contribution of Traditional Main Street Activity Centres in Victoria. Essential

541

542 Sardari Sayyar S and Marcus L (2013) Designing difference: Interpreting and testing Jane Jacobs criteria for diversity in space syntax terms. In Proceedings of the 9th International Space Syntax Symposium (Kim YO, Park HT and Seo KW (eds)). Sejong Unviersity Press, Seoul, South Korea, Ref 094: 1-15.

Schönfeld KCV and Bertolini L (2017) Urban streets: Epitomes of planning challenges and opportunities at the interface of public space and mobility. Cities 68: 48-55.

Slavnic Z (2013) Immigrant small business in Sweden: A critical review of the development of a research field. Journal of Business Administration Research 2(1): 29-42.

\section{Statistics Sweden (2018) New Swedish citizens from 160 countries. See:} https://www.scb.se/en/finding-statistics/statistics-by-subject-area/population/populationcomposition/population-statistics/pong/statistical-news/swedens-population-2017-population-changes2/ (accessed 24/05/2018).

Statistics Stockholm (2017) Area facts. See: http://statistik.stockholm.se/omradesfaktax (accessed 8/04/2018).

\section{Stockholms Stad (2018) Översiktsplan för Stockholms Stad. See:} https://vaxer.stockholm.se/globalassets/tema/oversiktplan-ny_light/oversiktsplan-2018-0219.pdf (accessed: 15/06/2018).

Strano E, Nicosia V, Latora V, et al. (2012) Elementary processes governing the evolution of road networks. Scientific Reports 2: 1-8. 
567

568 Strano E, Viana M, da Fontoura Costa L, et al. (2013) Urban street networks, a comparative

569

570 analysis of ten European cities. Environment and Planning B: Planning and Design 40(6):

571

572 Talen E and Jeong H (2018) Does the classic American main street still exist? An exploratory

573

574

575

576

577

578

579

580

581

582

583

584

585

586

587

588

589

590

591

592 Zukin S, Kasinitz P, and Chen X (2016) Global Cities, Local Streets. Routledge, New York, NY, look. Journal of Urban Design. See: https://doi.org/10.1080/13574809.2018.1436962 (accessed 16/06/2018).

Vaughan L, Sultan Khan S, Tarkhanyan L, et al. (2017). The Spatial Configuration of Minority Ethnic Business Diversity in London's High Streets. Proceedings of the 11th Space Syntax Symposium (Heitor T, Serra M, Pinela Silva et al. eds)) Lisbon, Portugal. Ref 151:1-12.

Tillväxtverket (2013) Företagare med utländsk bakgrund - Företagens villkor och verkligheten 2012. See http://www.ifs.a.se/wp-content/uploads/2012/12/Info_0393_web.pdf (accessed 29/05/2018).

Tillväxtverket (2015) Mångfald i näringslivet - Företagens villkor och verkligheten 2014. See: http://www.ifs.a.se/wp-content/uploads/2012/12/M\%C3\%A5ngfald-i-n\%C3\%A4ringslivetInfo_0594_web1.pdf (accessed 29/05/2018).

Thwaites K, Porta S, Romice O, et al. (2007) Urban sustainability through environmental design: approaches to time-people-place responsive urban spaces. Taylor \& Francis, New York, NY, USA.

593 USA.

594

595

Figure captions 
596 Figure 1. Map of Stockholm featuring three selected main streets. Top: Odengatan (Norrmalm);

597 middle: Hantverkargatan (Kungsholmen); bottom: Hornsgatan (Södermalm).

598 Table 1. The spatial structure and plot ownership per street

599 Table 2. Sizes and scales of the plates

600 Table 3. Change of plates per street

601 Table 4. Categorization of type of business

602 Table 5. Changes of category of business per street and for all streets

603 Table 6. Change in entrepreneurship per street and for all streets, and the share of migrants per 604 type of entrepreneurship 


\begin{tabular}{|c|c|c|c|}
\hline & Odengatan & Hantverkargatan & Hornsgatan \\
\hline Length of the street & 1750 meters & 1600 meters & 2300 meters \\
\hline $\begin{array}{l}\text { Number of blocks } \\
\text { plots }\end{array}$ & $\begin{array}{l}33 \text { blocks } \\
88 \text { plots }\end{array}$ & $\begin{array}{l}28 \text { blocks } \\
57 \text { plots }\end{array}$ & $\begin{array}{l}29 \text { blocks } \\
112 \text { plots }\end{array}$ \\
\hline Number of doors & $\begin{array}{l}\text { Residential } 84 \\
\text { Retail and non-retail } 209 \\
\text { Other } 28 \\
\text { Total } 321 \\
\text { door every } 5.45 \text { meter }\end{array}$ & $\begin{array}{l}\text { Residential } 65 \\
\text { Retail and non-retail } \\
136 \\
\text { Other } 25 \\
\text { Total } 226 \\
\text { a door every } 7.08 \\
\text { meter }\end{array}$ & $\begin{array}{l}\text { Residential } 130 \\
\text { Retail and non-retail } \\
304 \\
\text { Other } 69 \\
\text { Total } 503 \\
\text { door every } 4.57 \text { meter }\end{array}$ \\
\hline 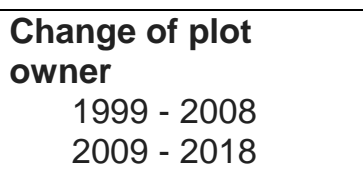 & $\begin{array}{l}32 \% \text { changed } \\
9 \% \text { changed }\end{array}$ & $\begin{array}{l}33 \% \text { changed } \\
27 \% \text { changed }\end{array}$ & $\begin{array}{l}36 \% \text { changed } \\
12 \% \text { changed }\end{array}$ \\
\hline $\begin{array}{l}\text { Plot ownership } 2018 \\
\text { (three largest) }\end{array}$ & $\begin{array}{l}\text { Cooperative } 51 \% \\
\text { Corporate company } 17 \% \\
\text { Insurance company } 12 \%\end{array}$ & $\begin{array}{l}\text { Cooperative } 48 \% \\
\text { Corporate company } \\
25 \% \\
\text { Municipal housing } \\
\text { company } 13 \% \\
\end{array}$ & $\begin{array}{l}\text { Cooperative } 51 \% \\
\text { Municipal housing } \\
\text { company } 20 \% \\
\text { Corporate company } \\
17 \%\end{array}$ \\
\hline
\end{tabular}

Table 1 The spatial structure and plot ownership per street 


\begin{tabular}{|c|c|c|c|}
\hline \multicolumn{4}{|c|}{2018} \\
\hline & Odengatan & Hantverkargatan & Hornsgatan \\
\hline $\begin{array}{l}\text { Plate size average } \\
\text { Minimum } \\
\text { Maximum } \\
\text { Median }\end{array}$ & $\begin{array}{l}146 \text { sq.m. } \\
30 \text { sq.m. } \\
1600 \text { sq.m. } \\
131 \text { sq.m. }\end{array}$ & $\begin{array}{l}113 \text { sq.m. } \\
25 \text { sq.m. } \\
420 \text { sq.m. } \\
93 \text { sq.m. }\end{array}$ & $\begin{array}{l}101 \text { sq.m. } \\
12 \text { sq.m. } \\
1307 \text { sq.m. } \\
80 \text { sq. m. }\end{array}$ \\
\hline Distribution of plates: & $100 \%$ & $100 \%$ & $100 \%$ \\
\hline "small” plates (up to 60 sq.m.) & $24 \%$ & $23 \%$ & $42 \%$ \\
\hline "medium" plates (61 - 120 sq.m.) & $36 \%$ & $39 \%$ & $37 \%$ \\
\hline "large" plates (121 - 180 sq.m.) & $23 \%$ & $14 \%$ & $8 \%$ \\
\hline "extra large" plates (from 181 sq.m.) & $17 \%$ & $24 \%$ & $13 \%$ \\
\hline
\end{tabular}

Table 2 Sizes and scales of the plates. 


\begin{tabular}{|l|c|c|c|}
\hline & Odengatan & Hantverkargatan & Hornsgatan \\
\hline Number of plates & 229 & 151 & 301 \\
2009 & 226 & 150 & 299 \\
2018 & $46.1 \%$ & $48.4 \%$ & $48.5 \%$ \\
\hline$\%$ change of plate activity & & & \\
\hline
\end{tabular}

Table 3 Change of plates per street 


\begin{tabular}{|c|c|c|c|}
\hline & \multicolumn{2}{|c|}{ Retail } & \multirow[t]{2}{*}{ Non-retail } \\
\hline & Product & Service & \\
\hline $\begin{array}{l}\text { Category } \\
\text { Type }\end{array}$ & $\begin{array}{l}\text { Retail product stores } \\
\text { Clothes, shoes, fashion; } \\
\text { Furniture and home } \\
\text { accessories; Retail stores (toy } \\
\text { store, office products, music } \\
\text { etc.); Florist; Second hand and } \\
\text { antique store; Book store }\end{array}$ & $\begin{array}{l}\text { Food and drink services } \\
\text { Restaurant-bar; Lunch deli, } \\
\text { bakery, ice cream shop and } \\
\text { coffee café (fresh products); } \\
\text { Fast food (limited seats, } \\
\text { take-away service); Hotel; } \\
\text { Night club }\end{array}$ & $\begin{array}{l}\text { Culture, } \\
\text { education and art } \\
\text { Gallery and } \\
\text { museum; Theater } \\
\text { and cinema; } \\
\text { Library; School; } \\
\text { Church }\end{array}$ \\
\hline $\begin{array}{l}\text { Category } \\
\text { Type }\end{array}$ & $\begin{array}{l}\text { Food retail product stores } \\
\text { Grocery store; Food-oriented } \\
\text { shop (limited fresh products); } \\
\text { Convenient store; Liquor store; } \\
\text { Specialized food store (cheese, } \\
\text { butcher, veg \& fruit) }\end{array}$ & $\begin{array}{l}\text { Personal beauty services } \\
\text { Nail salon, hair dresser and } \\
\text { solarium; Tattoo and barber } \\
\text { shop; Beauty and massage } \\
\text { salon; Gym and dance } \\
\text { studio }\end{array}$ & Offices \\
\hline $\begin{array}{l}\text { Category } \\
\text { Type }\end{array}$ & & $\begin{array}{l}\text { Commercial services } \\
\text { Computer and phone repair } \\
\text { service; Optician, } \\
\text { electronics, bike, jewelry, } \\
\text { photo (product and service } \\
\text { combined); Tailor, shoe, } \\
\text { lock \& key repair and dry } \\
\text { cleaning service; Pharmacy; } \\
\text { B2B and other commercial } \\
\text { services }\end{array}$ & Residential \\
\hline $\begin{array}{l}\text { Category } \\
\text { Type }\end{array}$ & & $\begin{array}{l}\text { Business and institutional } \\
\text { service } \\
\text { Formal service (Bank, } \\
\text { money exchange, travel } \\
\text { agency, funeral service, } \\
\text { property seller etc.); } \\
\text { Governmental and } \\
\text { municipal service; Doctor } \\
\text { and medical support }\end{array}$ & Vacant \\
\hline
\end{tabular}

Table 4. Categorization of type of business (source: author) 


\begin{tabular}{|c|c|c|c|c|}
\hline & \multicolumn{4}{|c|}{ Change from 2009 to 2018} \\
\hline & Odengatan & Hantverkargatan & Hornsgatan & All streets \\
\hline $\begin{array}{l}\text { Increasing } \\
\text { category of } \\
\text { businesses }\end{array}$ & $\begin{array}{l}\text { Food and drink } \\
\text { services (from } \\
16.5 \text { to } 24.3 \% \text { ) } \\
\text { Personal beauty } \\
\text { services } \\
\text { (from } 9.1 \text { to } \\
10.4 \% \text { ) }\end{array}$ & $\begin{array}{l}\text { Food and drink } \\
\text { services } \\
\text { (from } 22.2 \text { to } \\
26.8 \% \text { ) }\end{array}$ & $\begin{array}{l}\text { Food and } \\
\text { drink services } \\
\text { (from } 20.8 \text { to } \\
24.1 \% \text { ) } \\
\text { Personal } \\
\text { beauty } \\
\text { services } \\
\text { (from } 10.6 \text { to } \\
13.9 \% \text { ) }\end{array}$ & $\begin{array}{l}\text { Food and } \\
\text { drink } \\
\text { services } \\
+25.0 \% \\
\text { Personal } \\
\text { beauty } \\
\text { services } \\
+15.6 \%\end{array}$ \\
\hline $\begin{array}{l}\text { Decreasing } \\
\text { category of } \\
\text { businesses }\end{array}$ & $\begin{array}{l}\text { Retail product } \\
\text { stores (from } \\
27.4 \% \text { to } \\
23.0 \% \text { ) }\end{array}$ & $\begin{array}{l}\text { Retail product } \\
\text { stores } \\
\text { (from } 18.3 \text { to } \\
15.7 \% \text { ) }\end{array}$ & $\begin{array}{l}\text { Retail product } \\
\text { stores (from } \\
31.4 \% \text { to } \\
23.1 \% \text { ) }\end{array}$ & $\begin{array}{l}\text { Retail } \\
\text { product } \\
\text { stores - } \\
20.1 \%\end{array}$ \\
\hline
\end{tabular}

Table 5 Changes of category of business per street and for all streets 


\begin{tabular}{|l|c|c|c|c|c|}
\hline $\begin{array}{l}\text { Type of } \\
\text { entrepreneurship }\end{array}$ & \multicolumn{3}{|c|}{ Change from 2009 to 2018 } & 2018 \\
\hline Odengatan & $\begin{array}{l}\text { Hantverkargat } \\
\text { an }\end{array}$ & Hornsgatan & All streets & $\begin{array}{c}\text { Of which } \% \\
\text { migrant } \\
\text { businesses }\end{array}$ \\
\hline $\begin{array}{l}\text { Sole traders and } \\
\text { family businesses }\end{array}$ & $\begin{array}{c}\text { From 38.7 to } \\
33.0 \%\end{array}$ & $\begin{array}{c}\text { From } 40.5 \\
\text { to } 35.9 \%\end{array}$ & $\begin{array}{c}\text { From 33.0 } \\
\text { to } 31.7 \%\end{array}$ & $-9.6 \%$ & $40.5 \%$ \\
\hline Local companies & $\begin{array}{c}\text { From 22.2 } \\
\text { to } 19.6 \%\end{array}$ & $\begin{array}{c}\text { From 28.1 } \\
\text { to } 24.2 \%\end{array}$ & $\begin{array}{c}\text { From } 38 \\
\text { to } 27.1 \%\end{array}$ & $-21.5 \%$ & $33.5 \%$ \\
\hline $\begin{array}{l}\text { Chains } \\
\text { (international and } \\
\text { national) }\end{array}$ & $\begin{array}{c}\text { From 16.9\% } \\
\text { to } 21.8 \%\end{array}$ & $\begin{array}{c}\text { From 12.4 } \\
\text { to } 15.0 \%\end{array}$ & $\begin{array}{c}\text { From } 14.2 \% \\
\text { to } 19.8 \%\end{array}$ & $+31.7 \%$ & $9.2 \%$ \\
\hline Regional chains & $\begin{array}{c}\text { From } 5.7 \\
\text { to } 11.7 \%\end{array}$ & $\begin{array}{c}\text { From } 5.2 \% \\
\text { to } 11.1 \%\end{array}$ & $\begin{array}{c}\text { From } 7.3 \\
\text { to } 12.9 \%\end{array}$ & $+93.0 \%$ & $31.3 \%$ \\
\hline
\end{tabular}

Table 6 Change in entrepreneurship per street and for all streets, and the share of migrants per type of entrepreneurship 